\title{
Relationship Marketing as an Orientation to Customer Retention: Evidence from Banks of Pakistan
}

\author{
Benazir Solangi ${ }^{1}$, Urooj Talpur ${ }^{2}$, Sanober Salman Shaikh ${ }^{3}$, Tania Mushatque ${ }^{4} \&$ Muhammad Asif Channa $^{5}$ \\ ${ }^{1}$ Department of Public Administration, Shah Abdul Latif University Khairpur, Pakistan \\ ${ }^{2}$ Department of Economics, University of Sindh, Jamshoro, Pakistan \\ ${ }^{3}$ IBA, Sindh University, Jamshoro, Pakistan \\ ${ }^{4}$ Institute of Information Technology, University of Sindh, Jamshoro, Pakistan \\ ${ }^{5}$ Business Administration, Sindh University Campus Dadu, Pakistan \\ Correspondence: Sanober Salman Shaikh, Institute of Business Administration, Faculty of Commerce and \\ Business Administration, University of Sindh, Allama I.I. Qazi Campus, 76080, Jamshoro, Pakistan.
}

Received: April 16, 2019

doi:10.5539/ibr.v12n7p133
Accepted: June 17, $2019 \quad$ Online Published: June 27, 2019

URL: https://doi.org/10.5539/ibr.v12n7p133

\begin{abstract}
This study aims to underpin the relationship marketing as an orientation to customer retention. Further, this study undertakes the case study of banking sector from Sindh province, Pakistan. The reason of conducting this study was to analyze the impact of relationship marketing on customer's retention in the banking sector. Relationship marketing is getting more attention and popularity around the world and helps in developing customers satisfaction and loyalty. Quantitative research approach was used to measure the response of the sample. A field survey was conducted from customers of 20 banks operating in Larkana. An adopted questionnaire was used with five variables, four independent (Trust, commitment, communication and conflict handling) to predict one dependent variable (Customer retention) at 5-point Likert scale. The response was collected through close-ended questionnaire. The study has found that all the independent variables are positive and significant predictors of dependent variable with a good fit between their reliability and sample size adequacy. The major contribution of this study for the managers of banks particularly in Pakistani context is to take serious efforts to implement CRM effectively for customer retention in challenging marketing landscape due to technological and business extensions. The study has self-report nature so it cannot be generalized in all aspects. Research has left a gap for future research in the same set as well.
\end{abstract}

Keywords: relationship marketing, trust, commitment, communication, conflict handling, customer retention

\section{Introduction}

During the early 1990s era where the traditional marketing was done through transactional marketing but as so far world was moving into a millionaire $20^{\text {th }}$ century, the scenario was changed. New advancements in technology brought revolution in the field of service marketing which has rapidly grown over time.

Relationship marketing as a subject support strongly in today's rivalry environment resulted as a major weapon in strengthening the customer relationship management. In addition to basic concepts of marketing, relationship marketing is also said to be as advanced marketing concept. When the marketing moved from product concept to selling concept than to marketing concept, the relationship marketing has filled the gap between marketer and customers in strong customer relationship building (Chan, 2004). Relationship Marketing not only used as marketing orientation but also considered to be an as effective tool for updating customer information system (Abela, 2008).

Relationship marketing ultimately leads to modern business success (Webster, 2002). Thus, relationship marketing help marketer to update their marketing intelligence because it provides a base to the marketer to view latest customers related information (Ndubisi, 2004). It is notably identified by various studies that the in-service industry marketers can achieve external marketing success and high rate of value capturing from customers as customer retention, in this regard relationship marketing not only touches the customer retention but as well as long-lasting customer loyalty (Smith, 2000). Customer retention has supported optimizing marketers in effective 
implementation of relationship marketing orientation. The profitability level of companies can be easily increased with the effective customer retention by cutting off in taking new customers (Ahmad, 2001). The fruitful Customer retention leads to "reduce deficiencies" of best customers, so that customer's stir should be minimized. Customer's retention helps marketer in losing profitable customers (Farquhar, 2004). As so far, relationship marketing and customer retention in the banking sector, the customers with heavy deposits and having a healthy attitude towards banks can better retain by the banks.

According to Gronroos (1989), the business philosophy changed its way of doing marketing from a production orientation to selling orientation; meanwhile, service marketing had also got too much importance as arising in the field of marketing. The traditional marketing orientations were found in achieving only short-term marketing objectives but the relationship marketing had generated a new vitalize not only for achieving marketing objectives but also for creating and maintaining the long-run customer relations. Relationship marketing has got birth with the birth of service marketing (Sin, 2015).

The concept of relationship marketing had started from the early 1980s but formally shaped by Berry, Zeithaml and parasuraman (1993). Who defined it as Relationship marketing is a philosophy of building and maintaining the customer relationship. Gronroos (1991) determined that relationship marketing not only used for building and maintaining customer relationship but also can be used as an effective strategy to build relationships with other key stakeholders of acompany like suppliers, partners, service agencies. Harker (1999) explored the concept of relationship marketing that it is mutually beneficial for the companies.

Marketing literature highlights the relationship marketing as follows. Important contribution found in the field of relationship marketing comes from the research on guanxiwhich means "relationship" in English. Guanxiis a Chinese word used to make therelationship between two persons (Lawrence Ang, 2006). The personal selling literature witnesses that the relationship marketing is a bridge between front-line employees and the customers. According to Zeithaml, Berry and Parasuraman (1993), service industry cannot survive a single day without relationship marketing because service industry performance totally relies on the service performance attached to the service provider. The marketing channel literature also found evidence of the importance of relationship marketing. Service industry can better deliver the value to the final consumer if they are in a position to build and maintain fruitful relations with the intermediate channels (Ndubisi, 2005). Customer retention considered to be an interaction between manufacturers and the customers to bring together at one platform (Fang, 2008).

The banking sector is the largest service sector in Pakistan. The sector considered as major social force. Banks are currently facing significant environmental, social and economic challenges.. There is intense competition among banks for a profitable share of customers. So there is an acute need of strong marketing strategy to hold the customer share in the shape of high cutomer retention. Therefore, relationship marketing can help the banks in better management of firm-customer relationship and in achieving high level of loyality among customers. On the basis of past studies conducted on relationship marketing, this study reported relationship marketing as an orientation of customer retention. Therefore, the current was conducted with intention to examine the impact of relationship marketing on customers retention. Thus in this research the relationship marketing characterized is as; four-dimension; Trust, Commitment, Communication and Conflict Handling as an orientation of customer retention.

\section{Literature Review}

\subsection{Relationship Marketing}

Kotler (1992) said that companies have to shift from traditional marketing to relationship marketing to meet the market changes. According to Kotelrif the marketers are unable to coup up with modern challenges and are reluctant to adopt change then they will have the difficulties to survive. Kotler further suggested that relationship marketing can be very useful in developing the long term relationship. Current scenario of the market suggests that marketers should change their mindset from transaction marketing to relationship marketing because of rapid competition among service sectors (Johnston, 2001). Relationship marketing in the field of service marketing is considered to be the major customer-driven strategy (Wong, 2003). Relationship marketing is a way to complete the marketing process. By keeping in view relationship marketing, a marketer can be able to successfully formulate and implement other segmenting, targeting and positioning strategy (Lindgreen., 2004). According to relationship marketing is also used to control the effects of the microenvironment. Relationship marketing is a step to create, value delivery to the loyal customers and also suggests ways to be effectively captured from customers (Berry, 2002). Relationship marketing also provides a path for the strategic alliance by developing relations with the key actors of the company (Mintzberg, Daniel, McCarthay \& Markides, 2000).

Various studies have contributed towards the conceptualization of relationship marketing literature; trust (Ahmed, 
Husain, 2015; Morgan, 1994), commitment (Morgan \& Hunt, 1994; Ndubisi, 2004), conflict handling (Dwyer, Paul, Schurr, \& OH., 1987; Chan, 2004), and communication or sharing of secrets (Crosby, Evans, \& Cowles, 1990; Morgan \& Hunt, 1994). One of the major components of relationship marketing is trust on each other; it can be best defined as "the willingness towards accepting the exchange partner". Trust leads to shared values; ability to fulfill the promise is so-called trust. Trust creates obligations for the customers over marketers (O'Malley, 2014). In addition to trust, commitment is considered an important outcome of relationship marketing for effective customer relationship management and also increases firm reputation, a committed client becomes asource of information for affecting consumer behavior (Doorn, 2010). Communication is considered as the main pillar to create a relation between marketer and customer (Anderson, 2002). Communication is away to perform marketing functions from pre-selling to ultimate final consumption. Communication used to build strong trust in customers' mind; it supports marketers' promises made to customers for creating and delivering customer value (Smith, 2000). Communication is the process of exchanging valuable and timely information for achieving the desired objective.

\subsection{Customer's Retention}

Customer is key stakeholder for every kind of organization. Customer is considered as a king and customer satisfaction is prime concern for many organizations. The organization has to satisfy the customers at any cost (Nguyen, Nguyen, Nguyen, \& Phan , 2018). In this challenging evironment, customer loyalty has become a key issue for many firms and business. Because customer can be loyal if the service performance satisfied customer's needs and wants. Customer loyalty not only considered being as the source of revenue for the marketer but customer loyalty is strong source of the attracting new customers towards organizational success which encourage banks to retain customers through relationship marketing (Teng, 2018).

\subsection{Relationship Marketing and Customer's Retention}

The relationship marketing concept was first time given by (Berry, Zeithaml, \& Parasuraman, 1993). He defined relationship marketing is a multidimensional philosophy used to build and maintain effective customer relationship management. Furthermore, this concept was acknowledged by authors (Parasuraman, Berry, \& Zeithaml, 1993; Gronroos, 1999; Ahmed, Rafiq, \& Saad, 2003). Prior studies have found positive significant relationship between trust, continuous commitment and customer retention. Continuous commitment of service delivery creates trust in customer minds to be motivated (Ercis, Unal, Candan, \& Yildirim, 2012). Dimensions of relationship markeitng found significantly related with customer retention while measuring in different contexts, these dimensions had promoted behavirial aspect of loyalty which leads to ultimate retention (Putra \& Putri, 2019). Relationship marketing helps banks to achieve long term gains from customers and increased market share by devoting retained service delivery (Nyadzayo \& Khajehzadeh, 2016). The basic theme of relationship marketing in the field of service marketing is to strengthen the customer relationships management. The marketing literature provided idea of relationship marketing. Therefore, on the basis of past literature, most common dimensions of relationship marketing were chosen under this study and for further analysis hypothesis were set to investigate among banks of Larkana City. The hypothesis are as follows.

H1: Trust has a significant positive effect on customer retention (CR).

H2: Commitment has a significant positive effect on customer retention (CR).

H3: Communication has a significant positive effect on customer retention (CR).

H4: Conflict Handling has a significant negative effect on customer retention (CR). 


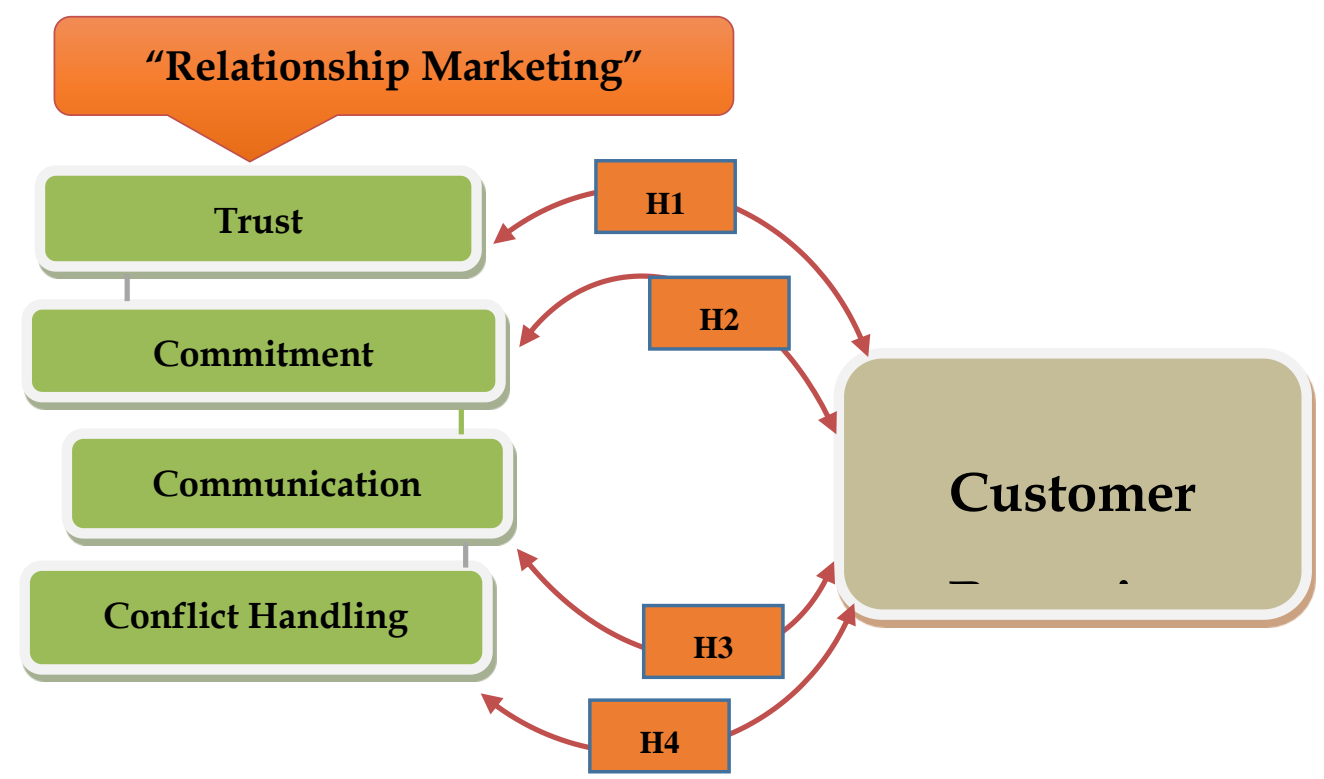

\section{"Nelson Oly Ndubisi (2007)"}

\section{Research Methodology}

Figure 1. Research Model

Based on the research objectives, the authors of this paper employed the quantitative research approach. Primary data was obtained through survey questionnaire on five-point Likert scale was administrated in the field among the respondents. As so far, Trust was measured by using Churchill and Surprenant (1982), communication by Morgan (1994), "commitment and conflict handling" measured by (Bloemer, De Ruyter, \& Wetzels, 1999) customer retention by measuring the scale of (Wright \& Riebe, 2010). Total 20 banks were selected data collection. Round about six hundred questionnaires were distributed among customers from whom four hundred fully filled questionnaires were returned. Daniel (1999) proposed the sample size determination method, it is applied to set a particular limit for sample of customers.

\section{Findings}

\subsection{Validity and Relaibility Test}

Table 1. Relaibility and Validity Results

\begin{tabular}{lcccc}
\hline & Cronbach's & rho_A & $\begin{array}{l}\text { Composite } \\
\text { Reliability }\end{array}$ & $\begin{array}{l}\text { Average Variance } \\
\text { Extracted (AVE) }\end{array}$ \\
\hline Trust & 0.952 & 0.954 & 0.958 & 0.640 \\
Commitment & 0.876 & 0.878 & 0.910 & 0.670 \\
Communication & 0.918 & 0.920 & 0.933 & 0.635 \\
Conflict Handling & 0.849 & 0.851 & 0.855 & 0.590 \\
Customer Retention & 0.809 & 0.811 & 0.824 & 0.613 \\
\hline
\end{tabular}

For considering internal consistency the cronabch's alphas should be greater than 0.70 (Nunlay, 1978). Specifically, all the five variables have cronbach's alphas value greater than the its critical value 0.70 , supporting the internal consistency evidence. Trust and communication has greater than 0.90 , commitment, conflict handling and customer retention has greater than 0.80. Advocating that the collected response is enough consistent in nature for further analysis. The convegent validity of scale was measured with the help of AVE value. As shown in table the AVE values are greater than 0.50 which evident as the scale is validateted to processed ahead (Yap, 2012). See Table 1.

The technique Kaiser- Mayer-Olkin measures the sample size adequacy with the support of Bartlett's Sphere city level. If the KMO value is 0.6 or above, then the study can be carried forward. The outcomes describe that KMO values are greater than the standard required thus it meets the level of sample size adequacy. For further details, see Table 2. 
Table 2. Results of Sample Adequacy Test

\begin{tabular}{|ccc|}
\hline \multicolumn{3}{c|}{ Factor Analysis } \\
\hline & KMO Measure of & Bartlett's Test of Sphericity \\
\hline Variable Names & Sampling Adequacy & \\
\hline & & .00 \\
Trust & .812 & .00 \\
Commitment & .816 & .00 \\
Communication & .815 & .00 \\
Conflict Handling & .723 & .00 \\
Customer Retention & .762 & \\
\hline
\end{tabular}

4.2 Hypothesis Testing

Table 3. Results of Hypotheses Testing

\begin{tabular}{llllll}
\hline & Total Effects & & & \\
\hline Path & $\begin{array}{l}\text { Std. } \\
\text { beta }\end{array}$ & $\begin{array}{l}\text { Std. } \\
\text { error }\end{array}$ & $\begin{array}{l}\text { t. } \\
\text { values }\end{array}$ & $\begin{array}{l}\text { p. } \\
\text { values }\end{array}$ & Decision \\
Trust $->$ Customer Retention & 0.435 & 0.049 & 8.790 & 0.000 & Supported \\
Commitment $->$ Customer Retention & 0.364 & 0.042 & 8.711 & 0.000 & Supported \\
Communication $->$ Customer Retention & 0.389 & 0.055 & 7.120 & 0.000 & Supported \\
Conflict Handling $->$ Customer Retention & 0.171 & 0.057 & 2.988 & 0.001 & Supported \\
Note: Centered on one tailed test with the 1000 bootstrapping at $\mathrm{p}<0.05$. & & & & \\
\hline
\end{tabular}

4.2.1 Hypothesis 1 Trust Has Significant Positive Relationship with Customer Retention (CR)

The results indicate the fitness of model and hypotheses test, from above it was concluded that the H1, was found supported because the IV(Trust) found positive impact on DV (Customer Retention), and thus Trust is predicting $66 \%$ customer retention at $\mathrm{p}=0.000$ significant level. Details are given in Table 3 .

\subsubsection{Hypothesis 2 Commitment Has Significant Positive Relationship with Customer Retention (CR)}

The results of Hypothesis 2 put an empirical evidence from customers of banks. As results suggest that the Commitment has predicted customer retention $72 \%$ with the positive Beta value by meeting the significant level as well thus hypothesis was found supported. Go to Table 3 .

\subsubsection{Hypothesis 3 Communication Has Significant Positive Relationship with Customer Retention (CR)}

The disclosure of findings of variable concludes that Communication has "significant positive impact on customer retention. The results show that the model is fit and significant at " $p=0.05$ ". Independent variable is $64 \%$ predicted. Find details in Table 3.

4.2.4 Hypothesis 4 Conflict Handling Has Significant Negative Relationship with Customer Retention (CR)

The results quantify that the conflict handling is sufficient predictor of customer retention because responses elaborated the positive and significant relationship between these subsequent variables. The table illustrates the conflict handling is $78 \%$ predicting the customer retention with a positive Beta value that is at all a good sign for managers. See Table 3.

\section{Discussion}

The results of this study exert an insight in the field of relationship marketing in banking sectors. The rapid development of the banking sector has generated a challenge for bankers to retain the customers but it's relationship marketing that enables bankers to hold the minds of customers with them. The study has investigated a lot for managers to think and implement relationship marketing. As results suggest that all the trust, commitment, communication and conflict handling ability is enough for customers' retention in today's challenging landscape. In meantime, this study encouraged the managers to analyze the theory and practice in customer retention in current market challenges. In particular, this study is much valuable because it covers all the aspects of employee analysis from the customers' point of view. The customers have shown their response for their dealings with the employees. How well employees are treating them for building and maintain long-lasting relations. Thus, this study can put a step towards to effective customer relationship management. As 
now marketing tends to be converted towards CRM. The study pointed to the proper justification for both managers and customers because in multi-transactional customers' bank holds is a critical situation at all. Thus customer retention in banking sector found a challenge. The results of this study invite bank managers to be more trustworthy, well committed in service delivery, efficient communicators in information sharing and should be leadership skills to handle all the conflicts created by customers and employees.

The practice of customer retention to be found effective in the banking sector with the help of relationship marketing can be best underpinned by the literature and concepts provided in the framework. The responses have also major contributors to support managers to formulate strategies for customer retention. Therefore, on the basis of given responses, it was found fair to conclude that the customers of banks in Larkana tend to be loyal and retained if they got fruit from managers' relationship marketing applications. When the customers have found employees trustworthy, committed, sophisticated in communication and able to resolve the conflict they tend to be loyal and retained.

The estimates show positive results that the higher the implications of these strategies, higher the degree of customer retention. Outcomes best conclude that the higher the customer trusts the bank, the commitment will increase more trustworthy and timely its interactions and the more suitably it resolves conflict, the more devoted its customers will have a tendency to be. Thus, this study has created a belief for bankers of Pakistan that the way they are looking forward for organizational success only possible with loyal customers, retained customers with banks through relations they developed and maintained. Banks should deliver at a great importance to satisfy customers as the customers become their advocates in given market place.

\section{Implications}

This study will help the banks to develop their growth strategies in relation to customer relationship management and customer loyalty. If the banks, consider the customer relations as their key success factor though it will help them to retain fruitful return from customers.

Theoretically, research outcomes provide empirical evidence for the orientation on customer retention of four dimensions of relationship marketing: "trust, commitment, communication and conflict handling". It will be used to motivate other customers as well and may even expand their own interests. Retainers can also be sources of product development. Customer-centered-relationship marketing theoretically replacing the concept of four Ps in marketing literature as the relationship marketing found as emerging paradigm.

\section{Limitations of Study \&Future Research Directions}

In fact, the current study has covered major theories and applications regarding relationship marketing approaches used for customer retention, but still there are several limitations relating to this study due to researcher capacity.

First, the research has only focused banking sectors and the nature of retention is longitudinal so these results cannot be applicable to other financial service providers or other organizations. Second, the sample was limited only in Larkana City so these cannot reflect the response at the general. Third, the sector selected for study has very unique characteristics, so the conclusions may be applicable to the banking sector only. Fourth, this study has captured the one-sided response from customers by ignoring the employees' perspective. Finally, limited literature and techniques were used.

Explanatory research used in this study put way for future research; the future researcher may longitude this study in other financial service sectors or other service providers. Population and sample size may be enhanced for getting more analyzed results. Advanced research techniques should be incorporated to analyze the results. Different research approaches may be used to explore the new insights in the field of relationship marketing. Model and survey instrument was adopted in this study; future researchers may develop their own. The focus of this study only limited to one marketing approach it may be elaborated with the help of other emerging marketing fields.

\section{References}

Abela, A. (2008). Marketing with integrity: ethics and the service-dominant logic for marketing. Journal of the Academy of Marketing Science, 36(1), 39-53. https://doi.org/10.1007/s11747-007-0062-0

Ahmad, N., Tarique, M. S., \& Hussian, A. (2015). Human resource practices and employee retention, evidences from banking sector of Pakistan. Journal of Business and Management, 186-188.

Ahmad, R. (2001). Customer retention: a potentially potent marketing management strategy. Journal of Strategic Marketing, 9, 29-45. https://doi.org/10.1080/713775729 
Ahmed, P. K., Rafique, M., \& Saad, N. M. (2003). Internal marketing and the mediating role of organizational competencies. European Journal of Marketing, 37(9), 1221-1241. https://doi.org/10.1108/03090560310486960

Anderson, J. A. (2002). A model of distributor firm and working partnerships. Journal of Marketing, 54(1), 42-58. https://doi.org/10.1177/002224299005400103

Berry L. L., Zeithaml V. A., \& Parasuraman A. (1993). Five Imperatives for Improving Service Quality. Sloan Management Review, 31(2), 29-38.

Berry, L. (2002). Relationship marketing of services: perspectives from 1983-2000. Journal of Relationship Marketing, 1(1), 59-77. https://doi.org/10.1300/J366v01n01_05

Bloemer, J., De Ruyter, K., \& Wetzels, M. (1999). Linking Perceived Service Quality and Service Loyalty: A Multi-Dimensional Perspective. European Journal of Marketing, 33, 1082-1106. https://doi.org/10.1108/03090569910292285

Chan, K. W. (2004). Examining the antecedents of relationship quality, customer satisfaction, and customer loyalty. (Unpublished MBA thesis). University of Malaysia Sabah, Kota Kinabalu.

Churchill Jr., G. A., \& Surprenant, C. (1982). An Investigation into the Determinants of Customer Satisfaction. Journal of Marketing Research, 19, 491-504. https://doi.org/10.1177/002224378201900410

Crosby, L. A., Evans, K. R., \& Cowles, D. (1990). Relationship quality in services selling: An interpersonal influence perspective. Journal of Marketing, 54, 68-81. https://doi.org/10.1177/002224299005400306

Daniel, W. W. (1999). Biostatistics: A Foundation for Analysis in the Health Sciences (7th edition.). New York: John Wiley \& Sons.

Doorn, J. L. (2010). Customer engagement behavior: theoretical foundations and research directions. Journal of Service Research, 13(3), 253-266. https://doi.org/10.1177/1094670510375599

Dwyer, F. R., Paul, H. S., \& Oh, S. (1987). Developing Buyer-Seller Relationships. Journal of Marketing 51(2), 11-27. https://doi.org/10.1177/002224298705100202

Ercis, A., Unal, S., Candan, B. F., \& Yildirim, H. (2012). The effect of brand satisfaction, trust and brand commitment on loyalty and repurchase intentions. Procedia: Social and Behavioral Sciences, 58, 1395-1404. https://doi.org/10.1016/j.sbspro.2012.09.1124

Fang, E. (2008). Customer participation and the trade-off between new product innovativeness and speed to market. Journal of Marketing, 72(4), 90-104. https://doi.org/10.1509/jmkg.72.4.90

Farquhar, J. D. (2004). Customer retention in retail financial services: an employee perspective. International Journal of Bank Marketing, 22(2), 86-99. https://doi.org/10.1108/02652320410521700

Gronroos, C. (1989). Defining marketing: a market-oriented approach. European Journal of Marketing, 23(1), 52-60. https://doi.org/10.1108/EUM0000000000541

Gronroos, C. (1990). Relationship approach to the marketing function in service contexts: the marketing and organizational behavior interface. Journal of Business Research, 20(1), 3-12. https://doi.org/10.1016/0148-2963(90)90037-E

Gronroos, C. (1999). Internationalization strategies for services. Journal of Services Marketing, 13(4/5), 290-297. https://doi.org/10.1108/08876049910282547

Harker, M. J. (1999). Relationship marketing defined? An examination of current relationship marketing definitions. Marketing Intelligence \& Planning, 17(1), 13-20. https://doi.org/10.1108/02634509910253768

Johnston, R. (2001). Linking complaint management to profit. International Journal of Service Industry Management, 12(1), 60-69. https://doi.org/10.1108/09564230110382772

Kotler, P. (1992). Marketing's new paradigms: What's really happening out there. Planning Review, 20(5), 50-52. https://doi.org/10.1108/eb054382

Lawrence, A. F. B. (2006). Customer retention management processes: A quantitative study. European Journal of Marketing, 40(1/2), 83-99. https://doi.org/10.1108/03090560610637329

Lindgreen, A. P. (2004). Contemporary marketing practice: theoretical propositions and practical implications. Marketing Intelligence \& Planning, 22(6), 673-692. https://doi.org/10.1108/02634500410559051

Mintzberg, H., Daniel J., McCarthy., \& Markides, C. (2000). Themes: Structure and Decision Making. The 
Academy of Management Executive 14(3), 31-42. https://doi.org/10.5465/ame.2000.4468063

Morgan, R. (1994). The commitment-trust theory of relationship marketing. Journal of Marketing, 58(3), 20-38. https://doi.org/10.1177/002224299405800302

Morgan, R. M., \& Hunt, S. D. (1994). The commitment-trust theory of relationship marketing. Journal of Marketing, 58(3), 20-38. https://doi.org/10.1177/002224299405800302

Ndubisi, N. O. (2004). Understanding the salience of cultural dimensions on relationship marketing, its underpinnings and aftermaths. Cross Cultural Management, 11(3), 70-89. https://doi.org/10.1108/13527600410797855

Ndubisi, N. O. (2005). Factorial and discriminant analyses of the underpinnings of relationship marketing and customer satisfaction. International Journal of Bank Marketing, 23(7), 542-557. https://doi.org/10.1108/02652320510629908

Ndubisi, N. O. (2007). Relationship marketing and customer loyalty. Marketing Intelligence \& Planning, 25(1), 98-106. https://doi.org/10.1108/02634500710722425

Nguyen, H. T., Nguyen, H., Nguyen, N. D., \& Phan, A. C. (2018). Determinants of Customer Satisfaction and Loyalty in Vietnamese Life-Insurance Setting. Sustainability 10, 1151. https://doi.org/10.3390/su10041151

Nunnally, J. C. (1978). Psychometric Theory (3rd ed.). New York: Organization for Economic Cooperation and Development, Paris, Maintaining Prosperity in an Ageing Society.

Nyadzayo, M. W., \& Khajehzadeh, S. (2016). The antecedents of customer loyalty: A moderated mediation model of customer relationship management quality and brand image. Journal of Retailing and Consumer Services 30, 262-270. https://doi.org/10.1016/j.jretconser.2016.02.002

O'Malley, L. (2014). Relational marketing: development, debates and directions. Journal of Marketing Management, 30(11/12), 1220-1238. https://doi.org/10.1080/0267257X.2014.939592

Parasuraman, A., Berry, L. L., \& Zeithaml, V. A. (1993). An empirical examination of relationships in an extended service quality model. MSI Report, 90-122. Marketing Science Institute: Cambridge.

Putra, W. J. A., \& Putri, D. P. (2019). The Mediating Role of Relationship Marketing between Service Quality and Customer Loyalty. Journal of Relationship Marketing. https://doi.org/10.1080/15332667.2019.1589246

Sin, L. Y. (2015). Relationship Marketing orientation: scale development and cross cultural validation. Journal of Business Research, 185-194. https://doi.org/10.1016/S0148-2963(02)00493-9

Smith, W. (2000). Reconsidering the relationship analogy. Journal of Marketing Management, 16, 81-94. https://doi.org/10.1362/026725700785100406

Teng, C. I. (2018). Managing gamer relationships to enhance online gamer loyalty: The perspectives of social capital theory and self-perception theory. Computers in Human Behavior, 79, 59-67. https://doi.org/10.1016/j.chb.2017.10.024

Webster, F. J. (2002). The changing role of marketing in the corporations. Journal of Marketing, 56(1), 1-17. https://doi.org/10.1177/002224299205600402

Wong, A. (2003). An examination of the relationship between trust, commitment and relationship quality. International Journal of Retail \& Distribution Management, 30(1), 34-50. https://doi.org/10.1108/09590550210415248

Wright, M., \& Riebe, E. (2010). Double jeopardy in brand defection. European Journal of Marketing, 44(6), 860-873. https://doi.org/10.1108/03090561011032748

Yap, B. W. (2012). Satisfaction and Trust on Customer Loyalty: a PLS approach. Business Strategy Series, Vol. 13(4), 154-167. https://doi.org/10.1108/17515631211246221

Zeithaml, V. A., Berry, L. L., \& Parasuraman, A. (1993). The Nature and Determinants of Customer Expectation of Service. Journal of the Academy of Marketing Science, 21 1-12. https://doi.org/10.1177/0092070393211001

\section{Copyrights}

Copyright for this article is retained by the author(s), with first publication rights granted to the journal.

This is an open-access article distributed under the terms and conditions of the Creative Commons Attribution license (http://creativecommons.org/licenses/by/4.0/). 